\title{
Francesca Fauri (ed.), The History of Migration in Europe: Perspectives from Economics, Politics and Sociology
}

Routledge, London, New York, 2015

V zadnjih tridesetih letih je v Evropi opaziti vse večje zanimanje za preučevanje migracij. K temu je prispevalo dejstvo, da se je kontinent po drugi svetovni vojni iz izseljenske dežele spremenil v »obljubljeno« deželo, najprej za države južnega Sredozemlja, sčasoma pa za vse širše mednarodno območje. Pojav poziva Evropo na soočenje s prišleki in z njihovo drugačnostjo, hkrati pa ji narekuje poznavanje lastne migracijske preteklosti in premišljevanje o migracijskem pojavu kot sooblikovalcu njene zgodovine in identitete. Pravo poplavo študijske produkcije vse pogosteje spremljajo tudi pregledi dognanj ter premisleki paradigem in epistemoloških vprašanj. Tako je tudi delo, o katerem poročam; nastalo je kot prispevek k preseganju zgolj ekonomističnih tolmačenj migracijskih procesov, ki so v zadnjih 50 letih prevladovali v ekonomski akademski stroki, in k branju migracijskega dogajanja kot kompleksnega součinkovanja materialnih stališč in nematerialnih dejavnikov. Delo združuje prispevke strokovnjakov s področij demografije, ekonomske, družbene in pravne zgodovine, sociologije in politologije, ki razpravljajo o treh tematskih sklopih: o opredelitvi migrantov, o razmerjih med migracijami in politiko ter o povezavi med migracijami in državljanstvom.

Prva tema, ki se ji posveča pet prispevkov, je že od nekdaj med primarnimi vprašanji metodološke debate. Samo razumevanje pojava je odvisno od terminoloških in konceptualnih formulacij, saj te lahko popačijo njegove dejanske dimenzije, značilnosti in naravo. Jan in Leo Lucassen utemeljujeta model merjenja migracijskih gibanj v dolgi časovni perspektivi, ki premošča klasične tipološke klasifikacije in se hkrati izogiba vključevanju vseh vrst mobilnosti. Model temelji na pojmovanju migracij kot načinih prehajanja med kulturnimi prostori, ki se ne dogajajo le na daljših relacijah in s prečkanjem državnih ali drugih upravnih meja. Na tej podlagi pridobljene ugotovitve med drugim kažejo, da je večina evropskih migracijskih gibanj od 16. stoletja odpadla na začasne ali trajne premike v mesta, da »veliko izseljevanje« v 19. in prvi polovici 20. stoletja ni bil največji migracijski pojav tega obdobja in da so bile migracije najintenzivnejše v prvi polovici 20. stoletja, ko so dve tretjini evropskega prebivalstva predstavljali migranti.

Paola Corti piše o stereotipnem povezovanju evropskih migracij z industrializacijo in o posledičnem prikazovanju predmoderne družbe kot sedentarne. To tezo so v zadnjih 30 letih razgradile zgodovinske raziskave, ki migracij ne interpretirajo več kot izredne pojave, povezane z velikimi zgodovinskimi prelomi, in ugotavljajo, da sedentarnost ali ustaljenost nista »naravni«, ampak idealizirani družbeni obnašanji. V dobi modernizacije je prišlo do velikega porasta migracij transnacionalnih in svetovnih razsežnosti, ki pa se tipološko prilagajajo že obstoječim vzorcem in novim razmeram. Ker je nacionalna država migracije $z$ namenom usklajevanja z ekonomskimi, s političnimi in z narodnimi interesi definirala in dokumentirala, so od takrat tudi bolj opazne. 
K velikemu izseljevanju v drugi polovici 19. stoletja vse do prve svetovne vojne so poleg ekonomskih dejavnikov v državah izseljevanja in deželah priseljevanja prispevali tudi drugi, med njimi je bila najvplivnejša prometna revolucija. Maria Elisabetta Tonizzi poudarja pomen mehanizacije pomorskega prometa, ki je okrepila in pocenila dostop do čezoceanskih trgov dela. Prevažanje izseljencev je s tem, da je prispevalo k razvoju ladjarstva in pristanišč, postalo tudi velik gospodarski in industrijski posel. Povzročalo je tudi konkurenčne boje med ladjarskimi družbami, ki so imele v zakupu organizacijo velikega čezoceanskega izseljevanja in mobilizacijo delovne sile za ameriške potrebe.

V prispevku Thomasa Faista je v središču pozornosti koncept transnacionalnosti, ki ga avtor uporabi kot analitični model za ugotavljanje vpliva migracij na izboljšanje materialnih razmer posameznikov in družin. Pokaže se, da učinki transnacionalne migracije niso enoviti in so odvisni od poklicne kvalifikacije migrantov in sposobnosti integracije nekvalificiranih migrantov v državah sprejemnicah. Gianmarco Ottaviano razpravlja o ekonomski tezi, da priseljevanje povzroča upadanje cen dela domačih delavcev in poslabšanje njihovega položaja. Na odstopanja od te teze vplivajo kvalitativne razlike med priseljenimi in domačimi delavci, zaradi katerih imajo lahko ti od priseljevanja korist in izboljšanje svojega položaja.

Med vidiki zgodovine migracij, ki prihajajo vse bolj do izraza, sta migracijska politika in vloga organov ter institucij, pooblaščenih za pomoč migrantom. Francesca Fauri predstavlja zgodovino in delo mednarodnih organizacij, ki so po drugi svetovni vojni skrbele za politične in vojne begunce ter ekonomske migrante (IRO, UHNRC, ILO in ICEM). Posebno pozornost posveča Italiji, kjer je po restrikcijah v obdobju med obema svetovnima vojnama in zaradi kriznih razmer vladalo največje zanimanje za izseljevanje. V petdesetih letih 20. stoletja je med vsemi evropskimi državami Italija prispevala največji odstotek gospodarskih izseljencev, v šestdesetih letih se je ta trend umiril zaradi t. i. »ekonomskega čudeža«, s čimer je upadla tudi vloga mednarodnih organizacij. Hkrati je Italija promovirala in tudi dosegla liberalizacijo trga dela med članicami Evropske gospodarske skupnosti.

Cristina Blanco Sìo Lòpez in Paolo Tedeschi obravnavata ukrepe, ki jih je Evropska skupnost sprejela v odnosu do migracij in migrantov starih in novih članic, pozneje pa priseljencev iz neevropskih držav. To so bili najprej ustanovitev Evropskega socialnega sklada za pomoč migrantom in brezposelnim, nato sredi osemdesetih let šengenski sporazum o prostem gibanju evropskih državljanov, leta 2006 program Frontex za varovanje meja in leta 2008 Evropski pakt o priseljevanju in azilu. Do zgodovinskega miselnega prehoda $v$ evropski migracijski politiki je prišlo ob začetku množičnega priseljevanja iz neevropskih držav.

Irska je v preteklosti med deželami izseljevanja in po številu izseljencev po svetu prednjačila, v zadnjih desetletjih pa je postala dežela priseljevanja. Velik porast števila priseljencev je med Irci vzbudil negativna čustva in zahteve po restriktivni imigracijski politiki. Te vidike razčlenjuje Cormac O' Gràda, ki uporablja zanimive primerjave iz časa pred prvo svetovno vojno, ko so bili tujci, čeprav številčno komaj zaznavni, že 
deležni diskriminatornih odnosov. $V$ središču razprave so tudi vprašanja, povezana s socialno državo in neto prispevkom, ki ga priseljenci dajejo družbi. Kljub temu se zaradi specifičnih primerov priseljevanja z namenom koriščenja socialnega sistema odpor do priseljencev povečuje. Mednje spada pojav ilegalnega priseljevanja nosečnic z namenom pridobitve irskega državljanstva, ki ga je zakon do leta 2004 priznaval na irskih tleh rojenemu otroku in materi.

Sandro Rinauro razpravlja o pojavu ilegalne migracije, s katero se Italija sooča vse od svojega nastanka. Do prve oziroma druge svetovne vojne je bil pojav povezan z omejevanjem svobode izseljevanja, $v$ fašističnem obdobju pa s preganjanjem nasprotnikov režima. Po drugi svetovni vojni se je nadaljeval v še večjem obsegu, ker je država tolerirala odhajanje ekonomskih izseljencev brez ustreznih dokumentov. Danes pa je vir težav priseljevanje iz afriških držav, ki je doseglo masovni značaj. Glavni vzrok ilegalnega priseljevanja in bivanja na italijanskih tleh je črna ekonomija in izkoriščanje nelegalnega dela, na čemer temeljijo številni gospodarski sektorji, medtem ko je za oblike ilegalnega priseljevanja odgovorna neustrezna zakonodaja.

V zadnjih desetletjih je v Italiji zelo občuten tudi pojav »bega možganov«, o katerem razpravljata Donatella Strangio in Alessandra De Rose na primeru izseljevanja v Avstralijo. Po ekonomskih migracijah do prve svetovne vojne in zlasti po njej, je to tretji t. i. veliki val izseljevanja na kontinent »tam spodaj«. Kot odgovor na krizne razmere, deficitarno politiko dela in vse slabše pogoje zaposlovanja mladih izobražencev $v$ italijanskem ekonomskem sistemu se je precej nepričakovano pojavil na začetku tretjega tisočletja. Avstralija je postala pomemben cilj zaradi programov, ki kljub restriktivni, a hkrati elastični politiki priseljevanja odpirajo mladim tujcem različne možnosti dostopa do delovnega trga.

Tretji tematski sklop, posvečen problematiki priseljevanja in državljanstva, se začenja s prispevkom Pierra Tyllija o priznanju volilne pravice priseljencem evropskih in drugih držav pri volitvah krajevnih uprav v Belgiji. Pot do tega priznanja je bila dolga in je vodila prek ekonomske integracije in postopne participacije priseljencev v javnem življenju, uvedbe legalnega koncepta evropskega državljanstva in končno do pridobitve volilne pravice in pravice do kandidiranja na občinskih volitvah. Dosega polnih političnih pravic pa je odvisna od pridobitve belgijskega državljanstva.

Posebna območja prepletanja med migracijami, državljanstvom in družbenim sodelovanjem so evropske mejne regije. $V$ njih potekajo tako ločevalni kot kooperacijski in povezovalni procesi med evropskim prostorom in sosednjimi državami. Dva taka primera, in sicer špansko enklavo Melillo na maroških tleh in sosednje maroško mesto Nador ter mesti Bari in Drač na italijanski oziroma albanski obali Jadranskega morja, analizirata Harlan Koff in Gloria Naranjo Giraldo. V obeh primerih gre za prehodni območji množičnega priseljevanja v Evropo, kjer so državne oblasti vzpostavile varnostne in upravne dispozitive za nadzorovanje meja in migracijskih tokov. Razlike pa so $v$ tem, da se $v$ maroškem primeru zaradi političnih ovir v odnosih med državama formalno politično sodelovanje omejuje na nadzor migracij, družbene, ekonomske ter kulturne izmenjave pa potekajo na neformalni ravni. $V$ primeru Barija 
in Drača pa sta evropska in lokalna politika pristopili k stvari bolj širokopotezno. Z investicijskimi programi in s čezmejnim sodelovanjem na ravni civilne družbe je prišlo tudi do gospodarske kooperacije in integracije, ki sta prispevali k dvigu ekonomije $v$ obeh mestih. Izboljšale so se tudi razmere za upravljanje migracijskih tokov v primerjavi z zgolj varnostnimi in represivnimi strategijami.

Delo končuje prispevek Debore Mantovani na temo identitete otrok priseljencev oziroma otrok iz mešanih priseljensko-italijanskih družin v Bologni. Italija, ki se po izseljenski preteklosti s šestimi milijoni tujcev (skoraj deset odstotki vsega prebivalstva) danes uvršča med večje evropske priseljenske države, se zato sooča z novimi modeli narodne identitete. Ti so, kot kaže raziskava, večpomenski, saj se potomci priseljencev istovetijo tako $z$ italijanskim kulturnim in narodnim okoljem kot $z$ etničnimi in kulturnimi vrednotami svojih staršev. Mešana ali kompleksna identiteta postaja normalen koncept tudi $v$ očeh italijanske mladine, ki pojem narodne, verske in kulturne pripadnosti vse bolj ločuje od pojma italijanskega državljanstva. Paleta identifikacij je vsekakor zelo široka in se spreminja v korelaciji s številnimi dejavniki, ki različno vplivajo na proces asimilacije. Pri najstnikih so pomemben dejavnik ohranjanja izvorne identitete ali integracije in prevzemanja italijanske narodne identitete tudi »prijateljske zveze«.

Aleksej Kalc 